\title{
Antimicrobial resistance and toxigenic profiles of bacteria isolated from tropical shrimps (Farfantepenaeus notialis and Penaeus monodon) in Cameroun
}

\author{
Sabine Ninelle Nga Ombede ${ }^{1}$, Victorien Dougnon ${ }^{2 *} \mathbb{B}$, Hornel Koudokpon ${ }^{2}$, Esther Deguenon ${ }^{2}$, \\ Rajeunie Pernelle Jaelle Mindzie Ngomo², Carine Tchibozo ${ }^{3}$, Jean Pierre Gnimatin², \\ François Tchoumbougnang ${ }^{1}$, Anges Yadouleton ${ }^{3}$ and Jacques Dougnon ${ }^{1}$
}

\begin{abstract}
Objective: Post-harvest shrimp losses are a big problem due to the proliferation of spoilage bacteria. Presence and multiplication of these bacteria promotes the emergence of food-borne diseases. This study was carried out to characterize some spoilage bacteria from tropical brackish water shrimps and black tiger shrimps stored in ambient temperature $\left(25^{\circ} \mathrm{C}\right)$

Results: 22 isolates of Bacillus spp; 09 isolates of Coagulase Negative Staphylococci (CNS) and 04 isolates of enterobacteria such as Pantoea spp (01); Serratia plymutica (01) and Serratia rubidaea (02) have been identified. Resistance and virulence genes were then detected. All isolates expressed resistance to at least three of antibiotics tested. 03 isolates of enterobacteria were susceptible to cetfazidim and amoxicillin-clavulanic acid. Bacillus spp showed total susceptibility to cefixim, ertapenem and cetfazidim. Staphylococci were susceptible to clindamycin. Pantoea spp was resistant to all antibiotics but exhibited intermediate susceptibility to amoxicillin-clavulanic acid. 04 isolates of Staphylococci were positive to mecA resistances genes. All the enterobacteria harbor no tetracycline resistance genes. All the isolates of Bacillus exhibited the presence of enterotoxin genes. Also, a high prevalence of 21 isolates to hemolytic enterotoxins was noted. 17 isolates from them kept ability to cell-lyse factor production like sphingomyelinase activities. The majority of Bacillus isolates identified by the present study poses a potential risk of food poisoning due to the prevalence of toxin genes found.
\end{abstract}

Keywords: Spoilage, Shrimps, Bacillus, Resistance genes, Enterotoxins

\section{Introduction}

Shrimps are great component of global seafood production. In general, they contain good quantities of digestible proteins, essential aminoacids, bioactive peptides,

\footnotetext{
*Correspondence: victorien88@hotmail.com

2 Research Unit in Applied Microbiology and Pharmacology of Natural Substances, Polytechnic School of Abomey-Calavi, University of AbomeyCalavi, Abomey-Calavi, Benin

Full list of author information is available at the end of the article
}

long-chain polyunsaturated fatty acids [1]. In Cameroun, tropical brackish water shrimp (Farfantepenaeus notialis) and black tiger shrimp (Penaeus monodon) are species widely consumed [2]. Shrimps are generally safe for consumption but their exposure to handling practices may occasionally entail health risks [3, 4]. Many retailers inappropriately stored shrimps in addition to poorly handling practices causing postharvest degradation [5]. Specific spoilage organisms will change characteristics of food as consequence of contamination [6]. Many studies showed

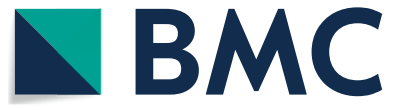

(c) The Author(s) 2020. This article is licensed under a Creative Commons Attribution 4.0 International License, which permits use, sharing, adaptation, distribution and reproduction in any medium or format, as long as you give appropriate credit to the original author(s) and the source, provide a link to the Creative Commons licence, and indicate if changes were made. The images or other third party material in this article are included in the article's Creative Commons licence, unless indicated otherwise in a credit line to the material. If material is not included in the article's Creative Commons licence and your intended use is not permitted by statutory regulation or exceeds the permitted use, you will need to obtain permission directly from the copyright holder. To view a copy of this licence, visit http://creativeco mmons.org/licenses/by/4.0/. The Creative Commons Public Domain Dedication waiver (http://creativecommons.org/publicdomain/ zero/1.0/) applies to the data made available in this article, unless otherwise stated in a credit line to the data. 
emergence of foodborne diseases due to spoilage bacteria [7]. Gram-positive bacteria are slightly dominant in tropical warm water [8]. This suggests their great implications in spoilage, especially at ambient temperature [9]. Foodborne illness could result from the fact that those bacteria harbor enterotoxins and resistance genes [7]. The aim of this study was then to explore antibiotics resistance and virulence factor of spoilage bacteria isolated from shrimps stored in ambient temperature $\left(25^{\circ} \mathrm{C}\right)$ in our markets.

\section{Main text \\ Materials and methods \\ Collection and storage of samples}

Experiments were carried out with $5 \mathrm{~kg}$ of tropical brackish water shrimp (Farfantepenaeus notialis) and the same quantity of black tiger shrimp (Penaeus monodon). The sampling took place from November to December 2018. Freshly harvested shrimp were purchased from 'Youpwe fisheries market' in Douala, Cameroon. Those samples were transported to the laboratory in iced box. They were then packed into four groups of $250 \mathrm{~g}$ portions per species in sterile plastic bags and kept at $-20{ }^{\circ} \mathrm{C}$ until lab processing. Every 2 days, one plastic bag from each species was randomly taken for enumeration and isolation of total spoilage bacteria. Before this, shrimps were removed from fridge and left at $25{ }^{\circ} \mathrm{C}$ for $24 \mathrm{~h}$ in the laboratory. This was done at room temperature because shrimps are sold in the markets without cold conditions and allowed spoilage odor to be produced.

\section{Identification of spoilage bacteria}

25 grams of shrimp per specie were aseptically added to $225 \mathrm{ml}$ of peptone water and homogenized [10]. Seven fold dilutions of each homogenate were prepared and $0.1 \mathrm{ml}$ of $10^{-7}$ dilution was used for enumeration and isolation on nutrient agar. Replicate plates were incubated in aerobiosis and in anaerobiosis at $37^{\circ} \mathrm{C}$. Thereafter counting, three characteristic isolates per plate were purified on Mueller Hinton. Pure isolates were stored at $-80{ }^{\circ} \mathrm{C}$ in $20 \%$ glycerol. Identification of bacterial isolates was then carried out using biochemical tests.

\section{Detection of resistance profile}

An overnight bacterial pre-culture was diluted to obtain a turbidity of 0.5 McFarland. Kirby Bauer techniques were used to perform susceptibility testing (Antibiogram Committee of the French Society of Microbiology, CASFM, 2012). Broth cultures were aseptically swabbed on Mueller Hinton agar. Antibiotic disks were placed on the agar plates and incubated $24 \mathrm{~h}$ at $37^{\circ} \mathrm{C}$. Inhibition zone diameters were measured after $24 \mathrm{~h}$. Susceptibility or resistance was determined according to CA-SFM (2012).
Antibiotic disks (HIMEDIA, India) used were amoxicillin $(30 \mu \mathrm{g})$, amoxicillin-clavulanic acid $(30 \mu \mathrm{g})$, cefixim $(5 \mu \mathrm{g})$, ceftazidim $(30 \mu \mathrm{g})$, ceftriazone $(30 \mu \mathrm{g})$, ciprofoxacin $(5 \mu \mathrm{g})$, clindamycin $(10 \mu \mathrm{g})$ colistin $(25 \mu \mathrm{g})$, ertapenem $(10 \mu \mathrm{g})$, erythromycin $(15 \mu \mathrm{g})$ fosfomycin $(50 \mu \mathrm{g})$, imipenem $(10 \mu \mathrm{g})$, nalidixic acid $(30 \mu \mathrm{g})$, oxacillin $(1 \mu \mathrm{g})$, penicillin $(10 \mu \mathrm{g})$, pristinamycin $(15 \mu \mathrm{g})$ and vancomycin $(30 \mu \mathrm{g})$.

\section{Molecular identification of antibiotic resistance genes}

DNA was extracted from the overnight colony obtained by spreading on Muller Hinton agar. DNA was extracted from isolates using Qiagen blue extraction kit. PCR mixture of $23 \mu \mathrm{l}$ contained 10 Nmole of genomic DNA, $0.5 \mu \mathrm{l}$ of each primer, $0.5 \mu \mathrm{l}$ dNTP, $2.5 \mu \mathrm{l}$ Buffer with $\mathrm{MgCl} 2$, $0.125 \mu \mathrm{l}$ Taq DNA Polymerase, and $16 \mu \mathrm{l}$ distilled water. For enterobacteria and staphylococci isolates, PCR detection was performed for the following different resistance genes : macrolide-resistance genes, vancomycin resistance genes, methicillin resistance genes and tetracycline resistance genes. PCR conditions included initial denaturation for $5 \mathrm{~min}$ at $94{ }^{\circ} \mathrm{C}$, followed by 40 cycles of denaturation for $45 \mathrm{~s}$ at $94{ }^{\circ} \mathrm{C}$, annealing for $55 \mathrm{~s}$ at $45^{\circ} \mathrm{C}$, extension for $90 \mathrm{~s}$ at $72{ }^{\circ} \mathrm{C}$ and final extension for $10 \mathrm{~min}$ at $72{ }^{\circ} \mathrm{C}$. PCR conditions for mecA were in accordance with those described by Igbinosa and Beshiru [11]. For Bacillus, virulence and enterotoxins genes were investigated. Genes encoding hemolysin (hbl-D/A), non-hemolytic enterotoxin (nheB), B. cereus enterotoxin $\mathrm{T}$ (bceT) and enterotoxin FM (entFM) were screened. Additional file 1: Table S1 show the primers used in the study. Virulence factors targeting genes coding for two phospholipases associated with cell lysis, sphingomyelinase (sph) and phosphatidylinositol-specific phospholipase C (piplc) were also investigated in accordance with Matarante et al. [12] and Mohammadou et al. [13]. PCR products were analyzed on $1.5 \%(\mathrm{w} / \mathrm{v})$ agarose gel stained $(120$ volts at $35 \mathrm{~min})$ with ethidium bromide $(0.5 \mu \mathrm{g} / \mathrm{ml})$ and visualized by UV. Additional file 1: Table S2 shows the primers of virulence factor genes detection.

\section{Results}

\section{Identification of spoilage bacteria}

Shrimps contained more than $10^{7}$ germs/g after $24 \mathrm{~h}$ in ambient storage. Additional file 1: Figure S1 shows the microbial population present in tropical shrimps. Results showed the main presence of Gram-positive bacteria such as Bacillus spp and Coagulase Negative Staphylococci (CNS). Some isolates of enterobacteria (Serratia spp and Pantoea spp) were also identified. 


\section{Resistance profile}

All the isolates of Coagulase Negative Staphylococci were susceptible to clindamycin. They showed total resistance to oxacillin and penicillin. The isolates were resistant to ciprofloxacin, colistin and vancomycin (55.56\%), to nalidixic acid (88.89\%). 15 isolates showed resistance to ceftazidim, ceftriaxon, cefixim and amoxicillin. Table 1 presents the antimicrobial susceptibility profile of Staphylococci.

Enterobacteria showed total resistance to ceftriazon, cefixim, amoxicillin and ertapenem. Only isolates of Pantoea spp showed intermediate resistance to amoxicillin-clavulanic acid and total resistance to all other antibiotics tested. Bacillus spp were susceptible to imipenem. 59.09\% of Bacillus spp exhibited intermediate resistance to ciprofloxacin and amoxicillin-clavulanic acid. Table 2 shows antimicrobial susceptibility profile of enterobacteria and Bacillus spp.

Table 1 Antimicrobial susceptibility of Staphylococci

\begin{tabular}{llllll}
\hline Antibiotics & S if $\geq$ & $\mathbf{R}$ if $<$ & $\mathbf{S} \%$ & $\mathbf{l} \%$ & $\mathbf{R} \%$ \\
\hline Ciprofloxacin & 25 & 22 & $3(33.33 \%)$ & $1(11.11 \%)$ & $5(5.56 \%)$ \\
Pristinamycin & 22 & 19 & $5(55.56 \%)$ & $1(11.11 \%)$ & $3(33.33 \%)$ \\
Penicillin & 29 & 18 & 0 & 0 & $9(100 \%)$ \\
Fosfomycin & 14 & 14 & $6(66.67 \%)$ & 0 & $3(33.33 \%)$ \\
Erythromycin & 22 & 17 & $5(55.56 \%)$ & $1(11.11 \%)$ & $3(33.33 \%)$ \\
Clindamycin & 15 & 15 & $9(100 \%)$ & 0 & 0 \\
Nalidixic Acid & 20 & 15 & $1(11.11 \%)$ & 0 & $8(88.89 \%)$ \\
Vancomycin & 17 & - & $4(44.44 \%)$ & 0 & $5(55.56 \%)$ \\
Oxacillin & 21 & 21 & 0 & 0 & $9(100 \%)$ \\
Colistin & 15 & 15 & $4(44.44 \%)$ & 0 & $5(55.56 \%)$ \\
\hline
\end{tabular}

$S$ sensible, $R$ resistant, / intermediate
Resistance and enterotoxins-virulence genes

Bacillus isolates isolated harbor at least two enterotoxins genes. Only one isolate was positive to hemolysin gene. Three isolates were negative to sph and piplo virulence genes. All Bacillus isolates (08) harbor Bacillus cereus enterotoxin $\mathrm{T}$ and also the sph gene. 04 isolates of Staphylococci exhibited the presence of MecA resistant gene. All enterobacteria isolates were tested negative to tetracycline resistance gene. Figure 1 shows the results of PCR product migration.

\section{Discussion \\ Identification of spoilage bacteria}

This study was carried out to explore resistance and virulence genes of spoilage bacteria isolated from shrimps in Cameroun. Results of this study are similar to those of Dabadé et al. [9] who mainly found positive Gram bacteria, especially lactic bacteria and enterobacteria in black tropical brackish water shrimp. Those Authors revealed that potentially spoilage bacteria in tropical shrimps in Benin may be $\mathrm{H}_{2} \mathrm{~S}$-producing dominant group of bacteria. Finding in this study suggests that Bacillus and Staphylococci species are responsible for spoilage detected in tropical shrimp. The results of this study are different from those of Srinivasan and Saranraj [14] who found Vibrio cholerae, Pseudomonas fluorescens, Salmonella Typhi, Staphylococcus aureus and Escherichia coli. These microorganisms are common in polluted water, so it is possible to find them in the seafood. The results obtained are comparable to those of Al Bulushi et al. [8] who who also isolated Staphylococci in their study. They also related that the frequency of Staphylococci in marine environments depend on geographic location. Bacillus species in coastal fisheries are also common, despite the relative abundance of Staphylococcus spp [8]. Abundance of Bacillus in coastal waters and marine fisheries depends

Table 2 Antimicrobial susceptibility of enterobacteria and Bacillus species

\begin{tabular}{|c|c|c|c|c|c|c|c|c|}
\hline \multirow[t]{2}{*}{ Antibiotics } & \multirow[t]{2}{*}{$S$ if $\geq$} & \multirow[t]{2}{*}{$R$ if $<$} & \multicolumn{3}{|c|}{ Enterobacteria } & \multicolumn{3}{|l|}{ Bacillus spp } \\
\hline & & & $\mathrm{S}$ & I & $\mathbf{R}$ & $\mathrm{S} \%$ & $1 \%$ & $\mathrm{R} \%$ \\
\hline $\begin{array}{l}\text { Amoxicillin - clavu- } \\
\text { lanic Acid }\end{array}$ & 23 & 16 & 3 & 1 & - & $8(36.36 \%)$ & 13 (59.09\%) & $1(4.55 \%)$ \\
\hline Vancomycin & 17 & - & 2 & - & 2 & 7 (31.82\%) & - & $15(68.18 \%)$ \\
\hline Ceftazidim & 21 & 19 & - & 1 & 3 & - & - & $22(100 \%)$ \\
\hline Impenem & 21 & 18 & 3 & - & 1 & 22 (100\%) & - & - \\
\hline Ciprofloxacin & 25 & 22 & 1 & 2 & 1 & $6(27.27 \%)$ & $6(27.27 \%)$ & $10(45.45 \%)$ \\
\hline Ceftriazone & 26 & 23 & & & 4 & 0 & $1(4.55 \%)$ & $21(95.45 \%)$ \\
\hline Cefixim & 25 & 22 & & & 4 & 0 & 0 & $22(100 \%)$ \\
\hline Amoxicillin & 23 & 16 & & & 4 & 0 & $1(4.55 \%)$ & $21(95.45 \%)$ \\
\hline Ertapenem & 28 & 26 & & & 4 & 0 & 0 & $22(100 \%)$ \\
\hline
\end{tabular}

$S$ sensible, $R$ resistant, / intermediate 


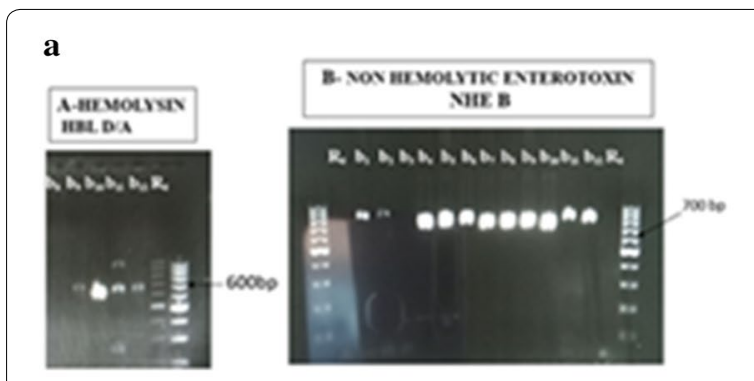

c

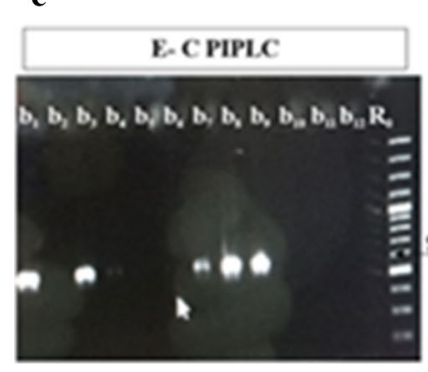

Fig. 1 PCR gene migration b

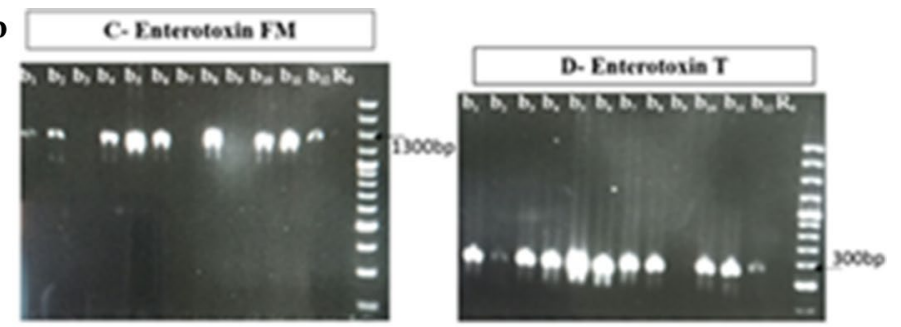

d
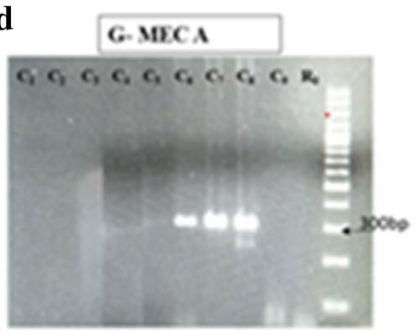

on temperature, depth and decline distance from the coast and, suggests that Bacillus species in coastal water originate from runoff [15]. Mohammadou et al. [13] reported Bacillus species such as Bacillus cereus, Bacillus thuringiensis and Bacillus anthracis were well-known as food poisoning in spoilage food. Gram-positive bacteria were more abundant than Gram-negative in tropical water. According to Al bulushi et al. [8], their influence in spoilage remain little probed. Findings of this study also showed low frequency of enterobacteria such as Serratia and Pantoea isolates who grow in a broad range of temperatures and substrates according to Garrity et al. [16]. Many species related with food spoilage, have been described as opportunistic human pathogens [17-19].

\section{Antimicrobial susceptibility profile}

The presence of Pantoea spp and Serratia spp in food is often neglected, when compared to classic multidrugresistant Gram-negative pathogens [20-22] likewise in this study. They are opportunistic pathogens among the most common causes of nosocomial diseases and transmissible by food ingestion. Resistance diversity of Bacillus isolates in the study is not similar to the works of Mohammadou et al. [13]. Those authors revealed relative susceptibility of Bacillus isolates to antibiotics unlike our results. Chaves et al. [7] also found susceptibilities of Bacillus isolated from Brazilian food to gentamicin and tetracycline. Drug resistance of isolates in this study may be attributed to the spores of Bacillus species. Mohammadou et al. [13] found that B. subtilus was able to produce bacteriocins such as subtilin in Mbuja.

\section{Resistance and enterotoxins-virulence genes}

Tetracycline resistance genes can be explored to current and emerging multidrug-resistant pathogens including carbapenem-resistant Enterobacteriaceae. None enterobacteria presented tetracycline resistance genes, although they were all resistant to ertapenem. MecA genes as presented in this study about Staphylococci are similar to those of Ali [23] and Igbinosa and Beshiru [11]. MecA gene is present in all Staphylococci isolates and is known to encode penicillin binding protein $2 \mathrm{a}(\mathrm{PBP} 2 \mathrm{a})$. Beta-lactam resistance is mostly attributed to mutations in mecA gene, but other genetic elements may also be considered for the explanation of the mechanism of resistance. Half of Bacillus isolates were positive to HBL genes. These results are similar to those of Chaves et al. [7]. The same authors demonstrated prevalence of hemolytic toxins in Bacillus isolates from fermented foods. Many authors correlate prevalence of enterotoxins HBL-NHE [24]. According to Trans et al. [25], wall peptidase (sph genes and PIPLC genes) are involved in adhesion, biofilm formation and virulence. Prevalence of entFM genes in more than half of Bacillus isolates is located on the chromosome and appears to be common to Bacillus thuringiensis and $B$. cereus. Detection of EntFM is similar to the results of Mohammadou et al. [13]. Presence of Bcet gene is evidence of presence of $B$. cereus among isolates. Agata et al. [26] also demonstrated that prevalence of this gene carried out other isolates than $B$. cereus. The majority of the isolates isolated pose a potential risk of food poisoning due to their antibiotic resistance profile and the prevalence of toxin genes found in Bacillus isolates. The surveillance of 
the quality control of those seafoods should be enhanced in the country, from the water to the final sellers. This is important and urgent to protect consumers' health.

\section{Limitations}

To better understand the links between spoilage and the bacteria involved, it would be useful to identify isolates using advanced methods as $16 \mathrm{~S}$ rRNA gene sequencing or species-specific PCR. The strains will be kept at $-20^{\circ} \mathrm{C}$ for sequencing in Helsinki (Finland).

\section{Supplementary information}

Supplementary information accompanies this paper at https://doi. org/10.1186/s13104-020-05184-1.

Additional file 1: Table S1. Primers of resistance genes. Table S2. Primers of virulence genes. Figure S1. Microbial population present in tropical shrimps.

\section{Abbreviation}

CNS: Coagulase Negative Staphylococci.

\section{Acknowledgements}

The authors are grateful to Prof Pascal HOUNGNANDAN, National University of Agriculture, Ketou (Benin) who allowed this collaboration between the both teams from Benin and Cameroon.

\section{Authors' contributions}

SNNO, FT and VD drafted the protocol. HK, ED, RPJMN, JPG, CT, AY performed the analysis. HK, ED and VD carried out the statistical analysis. SNNO, VD, ED wrote the draft of publication. AY and JD supervised the work and reviewed the manuscript. All the authors read and approved the final manuscript.

\section{Funding}

This study has been self-funded by the authors.

\section{Availability of data and materials}

All data generated or analyzed during this study are included in this published article and additional files.

\section{Ethics approval and consent to participate}

Not applicable.

\section{Consent for publication}

Not applicable.

\section{Competing interests}

The authors declare that they have no competing interests.

\section{Author details}

${ }^{1}$ Department of Processing and Quality Control of Fishery Products, Institute of Fisheries and Aquatic Sciences, Douala, Cameroon. ${ }^{2}$ Research Unit in Applied Microbiology and Pharmacology of Natural Substances, Polytechnic School of Abomey-Calavi, University of Abomey-Calavi, Abomey-Calavi, Benin. ${ }^{3}$ Reference Laboratory of Hemorragic Fevers in Benin, Ministry of Heath, Cotonou, Benin.

Received: 18 April 2020 Accepted: 14 July 2020

Published online: 29 July 2020

\section{References}

1. Venugopal $\mathrm{V}$, editor. Marine products for healthcare: functional and bioactive nutraceutical compounds from the ocean. London: CRC Press; 2009. pp. 221-39.

2. MINEPIA. Ministère de l'Elevage, des Pêches et des Industries Animales. MINEPIA Policy Document; 2014, p. 29.

3. Yang SP, Xie J, Qian YF. Determination of spoilage microbiota of Pacific white shrimp during ambient and cold storage using nextgeneration sequencing and culture-dependent method. J Food Sci. 2017:82(5):1178-83.

4. Don S, Xavier KM, Devi ST, Nayak BB, Kannuchamy N. Identification of potential spoilage bacteria in farmed shrimp (Litopenaeus vannamei): application of relative rate of spoilage models in shelf life prediction. LWT. 2018;97:295-301.

5. Nga Ombede SN, Kaktcham PM, Malang S, Zambou NF. Changes in sensory, physicochemical, and microbiological properties of fresh captured tropical pink shrimps (Penaeus duorarum notialis) inoculated with Lactobacillusplantarum Lp6SH, Lactobacillus rhamnosus Yoba, and their cell-free culture supernatants during storage at $4{ }^{\circ} \mathrm{C}$. J Food Saf. 2018. https://doi. org/10.1111/jfs.12579

6. Leisner JJ, Gram L. Spoilage of fish. In Encyclopedia of food microbiology. Academic Press; 2000, pp. 813-820.

7. Chaves JQ, Pires ES, Vivoni AM. Genetic diversity, antimicrobial resistance and toxigenic profiles of Bacillus cereus isolated from food in Brazil over three decades. Int J Food Microbiol. 2011;147(1):12-6.

8. Al Bulushi IM, Poole SE, Barlow R, Deeth HC, Dykes GA. Speciation of Gram-positive bacteria in fresh and ambient-stored sub-tropical marine fish. Int J Food Microbiol. 2010;138(1-2):32-8.

9. Dabadé DS, den Besten HM, Azokpota P, Nout MR, Hounhouigan DJ, Zwietering MH. Spoilage evaluation, shelf-life prediction, and potential spoilage organisms of tropical brackish water shrimp (Penaeus notialis) at different storage temperatures. Food Microbiol. 2015;48:8-16.

10. ISO. Norme ISO 4833-2: Microbiology of the food chain-Horizontal method for the enumeration of microorganisms-Part 2: Colony count at $30^{\circ} \mathrm{C}$ by the surface plating technique; 2013 .

11. Igbinosa EO, Beshiru A. Characterization of antibiotic resistance and species diversity of staphylococci isolated from apparently healthy farm animals. Afr J Clin Exp Microbiol. 2019;20(4):289-98.

12. Matarante A, Baruzzi F, Cocconcelli PS, Morea M. Genotyping and toxigenic potential of Bacillus subtilis and Bacillus pumilus strains occurring in industrial and artisanal cured sausages. Appl Environ Microbiol. 2004;70(9):5168-76.

13. Mohammadou BA, Le Blay G, Mbofung CM, Barbier G. Antimicrobial activities, toxinogenic potential and sensitivity to antibiotics of Bacillus isolates isolated from Mbuja, an Hibiscus sabdariffa fermented seeds from Cameroon. Afr J Biotech. 2014. https://doi.org/10.5897/AJB2014.13907.

14. Srinivasan T, Saranraj P. Isolation and identification of spoilage causing microorganisms in an Indian mackerel fish (Rastrelliger kanagurta). Int J Adv Res Biol Sci. 2017:4(7):1-7.

15. Rüger HJ, Fritze D, Spröer C. New psychrophilic and psychrotolerant Bacillus marinus isolates from tropical and polar deep-sea sediments and emended description of the species. Int J Syst Evol Microbiol. 2000;50(3):1305-13.

16. Garrity G, Bell JA, Lilburn T. The proteobacteria, Part B the gammaproteobacteria. Bergey's Manual Syst Bacteriol. 2005;2:323-79.

17. Delétoile A, Decré D, Courant S, Passet V, Audo J, Grimont P, Arlet G, Brisse S. Phylogeny and identification of Pantoea species and typing of Pantoea agglomerans isolates by multilocus gene sequencing. J Clin Microbiol. 2009;47(2):300-10.

18. Mahlen SD. Serratia infections: from military experiments to current practice. Clin Microbiol Rev. 2011;24(4):755-91.

19. Mardaneh J, Dallal MMS. Isolation, identification and antimicrobial susceptibility of Pantoea (Enterobacter) agglomerans isolated from consumed powdered infant formula milk (PIF) in NICU ward: first report from Iran. Iran J Microbiol. 2013;5(3):263.

20. Cunningham DJ, Leber A. Enterobacter, Cronobacter, and Pantoea species. In: Principles and practice of pediatric infectious diseases. Elsevier; 2018, p. 824-827.

21. Halpern M, Waissler A, Dror A, Lev-Yadun S. Biological warfare of the spiny plant: introducing pathogenic microorganisms into herbivore's tissues. 
In: Advances in applied microbiology, Vol. 74. Academic Press; 2011, p. $97-116$.

22. Melo DH, Souza BV, Nascimento JS, Amorim AMB, Medeiros LM, Mattoso JMV. A reddish problem: antibiotic-resistant Serratia marcescens in dairy food commercialized in Rio de Janeiro. Int Food Res J. 2018;25(2):880-3.

23. Ali HH. Isolation and identification of Staphylococcus bacteria from fish of fresh water and its antibiotics sensitivity in mosul city. Basrah JVet Res. 2014;13(1):33-42.

24. Boonchai N, Asano Sl, Bando H, Wiwat C. Study on cytotoxicity and nucleotide sequences of enterotoxin FM of Bacillus cereus isolated from various food sources. J Med Assoc Thai. 2008:91(9):1425-32.
25. Tran SL, Guillemet E, Gohar M, Lereclus D, Ramarao N. CwpFM (EntFM) is a Bacillus cereus potential cell wall peptidase implicated in adhesion, biofilm formation, and virulence. J Bacteriol. 2010;192(10):2638-42.

26. Agata N, Ohta M, Arakawa Y, Mori M. The bceT gene of Bacillus cereus encodes an enterotoxic protein. Microbiology. 1995;141(4):983-8.

\section{Publisher's Note}

Springer Nature remains neutral with regard to jurisdictional claims in published maps and institutional affiliations.
Ready to submit your research? Choose BMC and benefit from:

- fast, convenient online submission

- thorough peer review by experienced researchers in your field

- rapid publication on acceptance

- support for research data, including large and complex data types

- gold Open Access which fosters wider collaboration and increased citations

- maximum visibility for your research: over $100 \mathrm{M}$ website views per year

At BMC, research is always in progress.

Learn more biomedcentral.com/submissions 